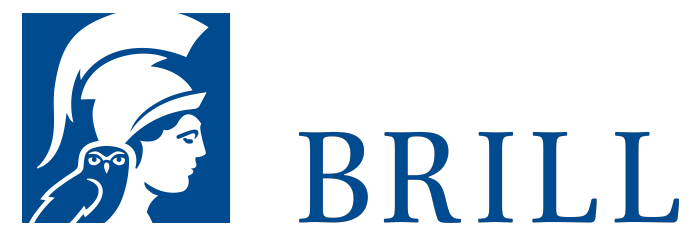

\title{
Vom Selbstbewußtsein zum Selbstverständnis
}

Kant und die Philosophie der Wahrnehmung

Author: Claus Langbehn

Als Klassiker ist Kant der Philosoph, der uns entlastet, indem er fragende Orientierung bietet und selbst dort noch von Bedeutung ist, wo man seine Stimme gegen ihn erhebt. Wo aber treffen wir auf Kant und die Philosophie der Wahrnehmung? Dieses Thema steht nicht im Vordergrund, weder in seinen Werken noch in der Geschichte nachkantischen Denkens. Kant ist nicht dafür berühmt, ein Philosoph der Wahrnehmung zu sein, eine einschlägige Wirkungsgeschichte muß erst noch geschrieben werden. Der Autor folgt dem Gedanken, daß man Kant als einen Philosophen der Wahrnehmung entdecken und für eine entsprechende Sicht auf die Geschichte nachkantischen Denkens fruchtbar machen kann. Kant und die Philosophie der Wahrnehmung ist in diesem zweifachen Sinne der Gegenstand der Untersuchung. Sie strebt ein neues Verständnis von Teilen der Kritik der reinen Vernunft an, fragt aber auch zugleich nach Möglichkeiten, weitere wahrnehmungsphilosophische Entwicklungen im 19. und 20. Jahrhundert vom Standpunkt dieses Werkes aus unter der Idee eines Weges vom Selbstbewußtsein zum Selbstverständnis zu diskutieren, insbesondere bei Fichte, Cassirer, Husserl und Heidegger. Im systematischen Mittelpunkt steht dabei die (konzeptualistische) Fragestellung, ob schon der Wahrnehmung ein begrifflicher Gehalt zukommt und, wenn ja, welchen Sinn er im Falle des Kantischen Konzeptualismus hat....

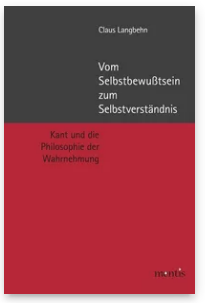

Pages: 364

Seiten

Language:

German

Subjects:

General,

Philosophy

Publisher: Brill | mentis

E-Book (PDF)

Released online: 20 Apr 2012

ISBN: $978-3^{-}$

89785-947-0

List price

USD $\$ 75.00$

Paperback

Publication date: 20 Apr 2012

ISBN: $978-3-$

89785-769-8

List price

USD $\$ 75.00$ 
For more information see brill.com

Order information: Order online at brill.com +44330 333 0049 | customerservices@brill.com Submission information: brill.com/authors

Titles published by Brill | Fink, Brill | mentis or Brill | Schöningh: +49(o)715413279216| brill@brocom.de 